\title{
Pilonidal Sinus of the Scalp: a Case Report and Review of the Literature
}

\author{
Olcay Ak Nalbant ${ }^{1}$, Erdem Nalbant ${ }^{2}$ \\ ${ }^{1}$ Laboratory of Pathology, Manisa State Hospital, Manisa, Turkey \\ ${ }^{2}$ Clinic of General Surgery, Merkez Efendi State Hospital, Manisa, Turkey
}

\begin{abstract}
A 31 -year-old man presented with a twenty-year history of a slowly growing nodule on his scalp in the postauricular area. The lesion was excised and with the clinical and histological findings, it was diagnosed as a pilonidal sinus. The purpose of this review is to report the unusual occurrence of a pilonidal sinus on the scalp and review the literature regarding especially this location.
\end{abstract}

Key Words: Pilonidal sinus, head and neck

Received: 23.10.2009 Accepted: 11.01.2010

\section{Introduction}

Pilonidal sinus is a chronic inflammatory condition associated with the penetration of hair fragments into the skin (1). It tends to occur frequently in the sacrococcygeal area, although rare cases have been described in other sites, including chin (1), neck (2), face (3), nose (4-6), scalp (7-10), supra-auricle area (11), external ear (12), interdigital space (13), and umbilicus (14). The purpose of this paper is to report an extremely rare case of pilonidal sinus of the scalp in the postauricular area, and review the literature regarding especially this location.

\section{Case Report}

A 31-year-old man presented with a 20-year history of a slowly growing nodule on his scalp of postauricular area. On physical examination, the patient had a $2 \times 2-\mathrm{cm}$, minimally mobile, slightly tender subcutaneous nodule. There was an orifice on the lesion, but intermittent discharge of pus from the orifice was not defined. There was no trauma history and he had no history of hair transplant, and he did not wear glasses.

A flap of skin was elevated and a spherical collection of hairs was seen. The lesion was surgically excised and sutured primarly (Figure 1). Specimens (Figure 2a) were fixed in neutral formaldehyde, embedded in paraffin, and stained with haematoxylin and eosin.

Histologically, hair shafts were embedded in the granulation tissue covered with benign squamous epithelium. There were a number of scattered foreign body giant cells, acute/ chronic inflammatory cells around the hair shafts (Figure 2b). A cyst wall with associated follicles and adnexal structures were not seen. Based on the clinical and histological findings, the case was diagnosed as a pilonidal sinus.

The patient has been well with no recurrence over a 5 month follow-up since surgery.

\section{Discussion}

Pilonidal sinus refers to any subcutaneous sinus which contains hair (6). The aetiology of pilonidal sinus remains unclear $(1,2,11)$. There are two main theories regarding its aetiology; acquired and congenital (3). The majority of opinions favour an acquired pathogenesis, with hormones, trauma, friction and infection, all having a role (2).

In general, at least three conditions need to be fulfilled for a pilonidal sinus to occur: first is hair in the skin and, second, some kind of wrinkled skin, such as the natal cleft or a scar. The third condition is a mixture of hormonal and hygienic problem (15).

All cases have not been explained by acquired causes. If there was no trauma history and the lesion was present for a long time or since birth, congenital causes should be thought of in the aetiology.

Pilonidal sinus is typically encountered in the sacrococcygeal region, but rare cases have been described at other sites (1-14). There are extremely rare cases at head and neck localizations in the literature. In this paper, we present most of all the cases and their features at head and neck localization in the literature (Table 1). 
Table 1. Literature review of pilonidal sinus of head and neck localization

\begin{tabular}{|c|c|c|c|c|c|}
\hline \multirow[t]{2}{*}{ Author's } & \multirow[t]{2}{*}{ Year } & \multirow[t]{2}{*}{ Age, Gender } & \multirow[t]{2}{*}{ Localization } & \multicolumn{2}{|c|}{ Aetiologic factor } \\
\hline & & & & Acquired (Trauma) & Congenital \\
\hline Oudit D et al. (1) & 2005 & $31, M$ & Chin & + & \\
\hline Meher R et al. (2) & 2006 & $24, M$ & Neck & + & \\
\hline O'Sullivan MJ et al. (3) & 2000 & $30, M$ & Face & + & \\
\hline Llambrich A et al. (4) & 2006 & $53, M$ & Nose & & + \\
\hline Schache DJ et al. (5) & 1989 & $13, M$ & Nose & & + \\
\hline Paulose $\mathrm{KO}$ et al. (6) & 1989 & $23, M$ & Nose & + & \\
\hline Chiu MW et al. (7) & 2008 & $70, F$ & Scalp & + & \\
\hline Kosaka M et al. (8) & 2007 & $4, M$ & Scalp & + & \\
\hline Moyer DG (9) & 1972 & $5, M$ & Scalp & + & \\
\hline Tromovitch TA (10) & 1972 & Unknown & Scalp & + & \\
\hline Yokoyama T et al. (11) & 2007 & $32, \mathrm{M}$ & Supra-auricle area & Unclear & \\
\hline Woodward WW (12) & 1965 & $27, M$ & External ear & Unknown & \\
\hline Present case & 2009 & $31, M$ & Scalp (post-auricler area) & Unclear & \\
\hline
\end{tabular}

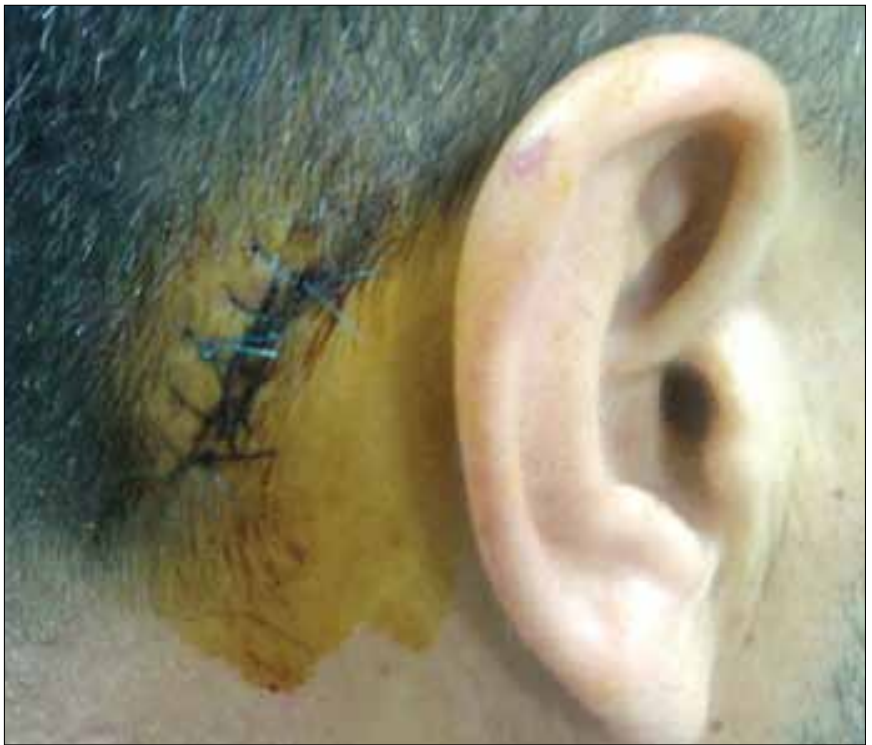

Figure 1. The lesion was surgically excised and sutured primarly

If hair is the first factor for pilonidal sinus, why do we not see more pilonidal sinus cases in the scalp? Scalp tissue is dry and rough, but, if there is trauma, broken hair easily drills into macerated skin. In the table, all cases of pilonidal sinus of scalp had trauma history. In the present case, there was no trauma history and, the lesion had been present for a long time, approximately 20 years. So, the essential aetiologic factor for this case is unclear.

Although this lesion is rare in the scalp, it should be included the differential diagnosis of subcutaneous head and neck nodules.

\section{Conflict of Interest}

No conflict of interest was declared by the authors.

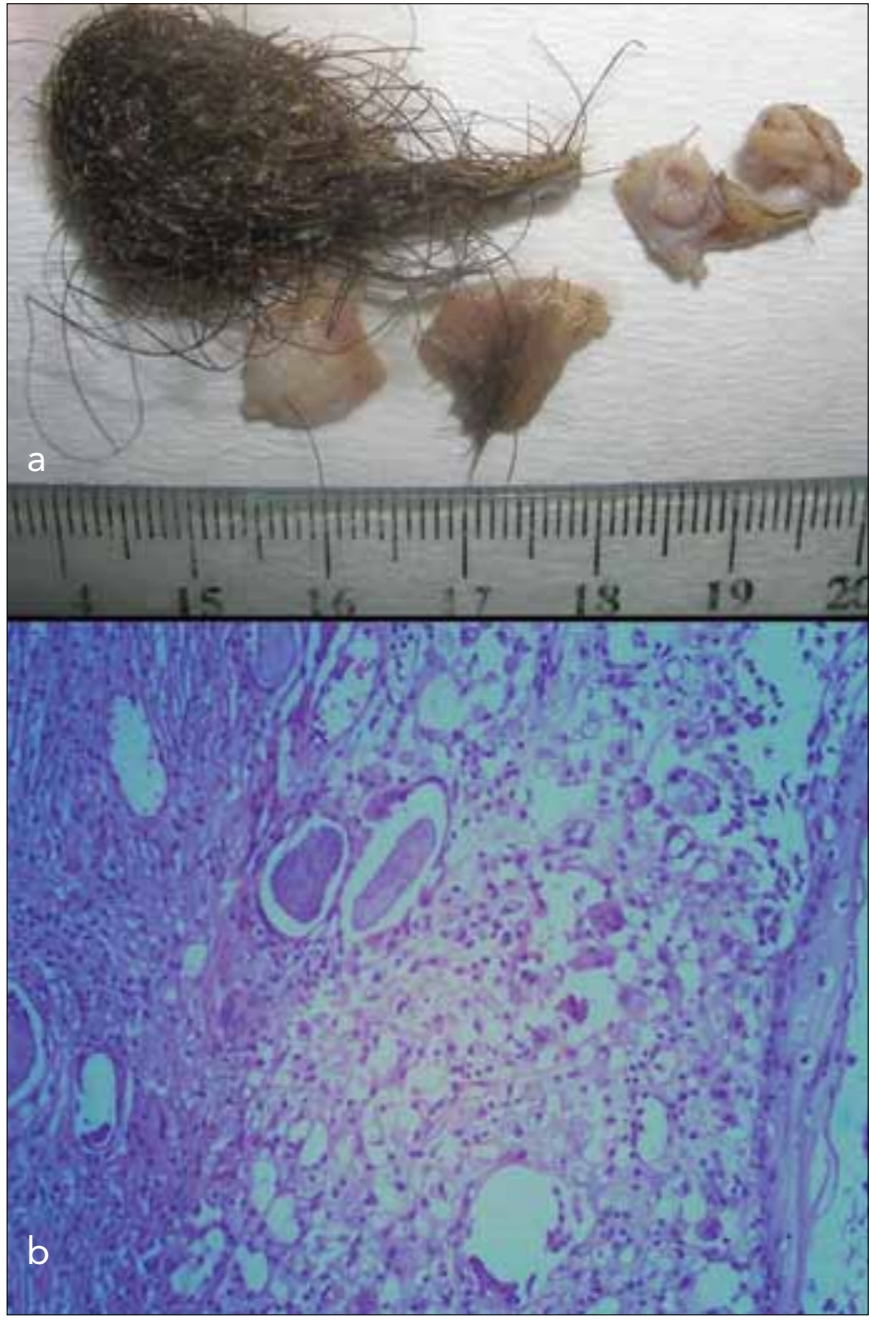

Figure 2. (a) Macroscopy specimens of the lesion. (b) The hair shafts were embedded in the granulation tissue covered with benign squamous epithelium (H\&E; x200) 


\section{References}

1. Oudit D, Ellabban M, Eldafl D, Crawford L, Juma A. Pilonidal sinus of the chin. Plast Reconstr Surg 2005;115:2153-4. [CrossRef]

2. Meher R, Sethi A, Sareen D, Bansal R. Pilonidal sinus of the neck. J Laryngol Otol 2006;120:e5. [CrossRef]

3. O'Sullivan MJ, Kirwan WO. Post-traumatic pilonidal sinus of the face. Br J Dermatol 2000;143:1353. [CrossRef]

4. Llambrich A, Rocamora V, García de la Torre JP, Sánchez MC. Pilonidal sinus of the nose. Eur Acad Dermatol Venereol 2006;20:1004-5.

5. Schache DJ, Stebbing A, Rees M. Congenital pilonidal sinus of the nose. Aust N Z J Surg. 1989;59:511-2. Comment in: Aust N Z J Surg 1992;62:497. [CrossRef]

6. Paulose KO, al Khalifa S, Raj SS, Saeed T. Pilonidal sinus of the nose. J Laryngol Otol 1989;103:1210-3. [CrossRef]

7. Chiu MW, Abrishami P, Sadeghi P. Letter: pilonidal cyst of the scalp. Dermatol Surg 2008;34:1294-5. Epub 2008 Jun 27.
8. Kosaka M, Kida M, Mori H, Kamiishi H. Pilonidal cyst of the scalp due to single minor trauma. Dermatol Surg 2007;33:505-7. [CrossRef]

9. Moyer DG. Pilonidal cyst of the scalp. Arch Dermatol 197;105:578-9.

10. Tromovitch TA. Pilonidal cysts of the scalp. Arch Dermatol 1972;106:601. [CrossRef]

11. Yokoyama T, Nishimura K, Hakamada A, Isoda KI, Yamanaka KI, Kurokawa I, et al. Pilonidal sinus of the supra-auricle area. J Eur Acad Dermatol Venereol 2007;21:257-8.

12. Woodward WW. A pilonidal sinus of the ear. Aust N Z J Surg 1965;35:72-3. [CrossRef]

13. Uysal AC, Alagöz MS, Unlü RE, Sensöz O. Hair dresser's syndrome: a case report of an interdigital pilonidal sinus and review of the literature. Dermatol Surg 2003;29:288-90. [CrossRef]

14. Schoelch SB, Barrett TL. Umbilical pilonidal sinus. Cutis. 1998;62:83-4.

15. Doll D, Petersen S. Trauma is not a common origin of pilonidal sinus. Dermatol Surg 2008;34:283-4. [CrossRef] 